\title{
Gondolatok a „másság”-ról és az elfogadásról saját történetem kapcsán
}

\author{
„... el kell fogadnunk a testünket, a testi életünket a fogamzástól a halálig.”
}

(Susan Wendell, 2011: 161)

Susan Wendell $A z$ elutasított test című könyvének „olvasása igazi intellektuális kaland" - fogalmaz ajánlójában Hernádi Ilona (Wendell, 2011). Számomra ezen túl saját történetem szűrőjén át nézve - megérintő, megrázó és felemelő élmény volt.

Egy vidéki városban születtem, várva várt első gyermekként. Szüleim ekkor még nem sejtették, hogy kislányuk egy viszonylag ritka genetikai betegséggel, örökletes spherocytosissal (ejtsd: szferocitózis) jött a világra.

A tünetek lassan alakultak ki, és az orvosok is leginkább a sötétben tapogatóztak. A diagnosztizálás nehézségeit mutatja az is, hogy betegségem egyik fö tünetét, a sárgaságot összetévesztették a fertőző májgyulladás okozta sárgasággal és leoltották hepatitis ellen a fél települést mire rájöttek, hogy nem fertőzök. Egészen a városi klinikáig kellett mennünk, hogy a pontos diagnózist valaki végre felállítsa. Ott jöttek rá, hogy egy hematológiai kórképről van szó. Az orvos próbálta kíméletesen közölni a tényeket, de elfelejtette, hogy a szüleim nem hematológusok, így félig latinul beszélt (spherocitózis, hemolízis, anémia, tranzfúzió, splenectómia, autoszomális domináns). A mamám szerint, ha magyarul mondta volna sem értette volna meg, mert csak annyit fogott fel az egészből, hogy gyógyíthatatlan és öröklődik.

Miután felocsúdtak a kezdeti sokkból, megértették, hogy a vörösvértest membránjának károsodása okozza a problémát. Emiatt a vörösvértestek idő előtt elpusztulnak, így nem tudják kellő ideig szállítani az oxigént a szervezetben. A hirtelen fellépő, nagyfokú vörösvértest-szétesésből származó anyagokat a máj nem képes feldolgozni, ezért sárgaság jelentkezik a bőrön és a nyálkahártyán. A csontvelő pedig nem tudja időben pótolni a szétesett vörösvértesteket és vérszegénység alakul ki. A fizikai megterhelés, a betegségek, a fertőzések, a nagy meleg és a kiszáradás fokozzák a vörösvértestek szétesését. Ezen kívül a lép fokozatosan növekszik, amit idővel ki kell majd venni. Többször lehet szükség vérátömlesztésre és 50\%-ban biztosan tovább öröklödik.

Azzal, hogy hematológiai gondozott lettem, egy egész életre szóló életmódra rendezkedtünk be. Folyamatosan jártunk vérvételre és igyekeztünk elkerülni az állapotom romlásával járó helyzeteket. Gyerekként én annyit érzékeltem az egészből, hogy 'más' vagyok, mint a többiek. Az óvodában/iskolában sárgás bőröm miatt, a hematológiai gondozóban pedig göndör fürtjeim miatt lógtam ki a többiek közül. (Később 
tudtam meg, hogy ők leukémiások voltak.) Nem voltam sem igazán egészséges, sem igazán beteg.

14 éves koromban - ahogy az orvosok azt megjósolták - egy hasi mütéttel el kellett távolítani növekvő lépemet. Kamasz lányként ez a mütét olyan nagy fizikai és pszichés megrázkódtatás volt, amit csak nehezen tudtam feldolgozni. Betegségem ekkor tudatosodott bennem. Andrew Solomon Szeress, bármi történjék című előadásában az elfogadásnak három szintjét említi: az önelfogadást, a családi elfogadást és a társadalmi elfogadást (Solomon, 2013). Hosszú időre volt szükségem, mire el tudtam fogadni saját testi állapotomat, $s$ a tényt, hogy gyógyíthatatlan betegséget örökítek. A folyamatot nehezítette, hogy a mütét és a betegség tudatosodása éppen kamaszkoromban történt, mely az identitás kialakulásának életszakasza. Miért pont velem történik ez? Kinek fogok így tetszeni? Hogyan lesz így családom?

Cheryl-Marie Wade az önérvényesítésről szóló filmjében így fogalmaz: „mindent meg kellene tennem azért, hogy ne tünjek fogyatékosnak, el kellene rejtenem azt", majd példaként említi Roosevelt elnököt, akit soha nem mutattak fogyatékosnak (Wade, 2012). Susan Wendell (2011) szerint is, aki teheti, többnyire mindenki elöl igyekszik elrejteni fogyatékosságát. Én hozzátenném, hogy nemcsak fogyatékosságát, hanem bármilyen (testi) hibáját igyekszik elrejteni az ember, ahogyan azt én is tettem az életem részét képező gyengeséggel és fáradékonysággal, illetve a hasamon éktelenkedő műtéti heggel. A miértre pedig szintén Wendell (2011) és Wade (2012) adja meg a választ: „... a legtöbb férfiuralta kultúrában a nőket inkább a testük alapján ítélik meg” és a „társadalom tagjainak a halált tagadó fiatalság, egészség és testi tökéletesség elvárásainak kell eleget tennie." Hosszú utat tettem meg az önelfogadás útján, mire képesnek éreztem magam értékesnek látni.

A párválasztás kérdése újabb próbatételek elé állított. Sok kudarc ért. A saját börömön tapasztaltam meg, hogy az emberek mennyire képesek idealizálni a testet. Aki nem tudta elfogadni a mütéti hegemet, azt már be sem avattam betegségem további részleteibe. Sokáig úgy éreztem, hogy nincs is jogom ilyen mértékben befolyásolni egy másik ember életét. Talán jobb lenne, ha nem is akarnék saját családot. Csak így tudnám megszakítani a hibás gén öröklődését... Szerencsére ennél a depresszív gondolatmenetnél erősebb volt bennem a „normális” életre való vágy.

Végül sikerült rátalálnom arra a csodálatos emberre, aki képes volt elfogadni annak, aki vagyok. Eleinte - ahogyan arról Solomon is beszél - természetesen tartottam attól, hogy hogyan fog majd a választott családom elfogadni (Solomon, 2013). Akarnak-e egy állandó gyengeséggel és fáradtsággal küzdő beteg nőt fiuk mellé? Képesek lesznek-e elfogadni, hogy unokájuk is beteg lehet? Aggodalmaim hamarosan elmúltak, mert új családom tagjai is feltétlen elfogadással fordultak felém.

A gyermekvállalás felelős döntés, kiváltképp a mi esetünkben. Mindent mérlegre tettünk: az 50\% esélyt, azt hogy alapvetően „minden szülö meg akarja védeni a gyerekét a betegségtöl” (Solomon, 2013), a betegséggel kapcsolatos saját testi és lelki tapasztalataimat és a gyermek iránti mérhetetlen vágyunkat. Ez utóbbi azonban mindent felülírt és hamarosan gyermekáldás elé néztünk. Minden rendben zajlott. Sem a várandósság, sem a szülés nem rontott hematológiai állapotomon, amit - ritka betegség lévén - nem tudhattunk elöre. Az is hamarosan nyilvánvalóvá vált, hogy gyermekünk örökölte a spherocytosist... és innentöl már ismerős a történet.

Andrew Solomon szerint csodálatos azt látni, hogy „mennyi értelmet találnak az emberek sérült gyermekük nevelésében” és „mennyi szeretet van jelen, még akkor 
is, amikor minden, ami csak tud, elromlik." Hiszen „az a szeretet, amit a gyermekeid iránt érzel, különbözik bármilyen érzéstöl a világon" (Solomon, 2013).

Három év múlva újból vállalkoztunk a nagy csodára, és a történet is újból megismétlődött. Ennek ellenére egy pillanatra sem bántuk meg, hogy a gyermekvállalás mellett döntöttünk. A szeretetteljes anya/apa-gyermek kapcsolaton kívül egy különleges kapocs „a különbségeink, és ahogy kezeljük azokat, az tart minket össze” (Solomon, 2013).

Mindkét gyermekem esetében a betegség enyhébb fokban jelent meg, kevésbé korlátozza őket a mindennapi tevékenységeikben. Például nem annyira fáradékonyak, mindketten tornázhatnak, sportolhatnak. Nagyobbik gyermekem már átesett a lépeltávolításon egy kíméletesebb, hasfal felnyitása nélkül végzett (laparoszkópiás) műtéttel, kisebbik gyermekemre még vár ez a megpróbáltatás. Betegségük egyensúlyban van, mindketten jól vannak.

Visszatérve Solomon (2013) elfogadásról elmondott gondolataihoz, saját tapasztalatom a társadalom elfogadásáról kettős. Volt olyan iskolai testneveléstanárom, aki nagyon nehezen értette meg, hogy - bár nem látszik rajtam semmi - nem véletlenül vagyok testnevelésből felmentve. Mindenáron ki akarta próbálni, hogy hány nagypályán futott kör után esek össze hemolitikus sokk miatt. Pozitívum pedig, hogy eddigi munkahelyeimen jól tolerálták betegségemet, és az azzal járó fáradékonyságomat. Jelenleg is úgy alakíthatom munkahelyi elfoglaltságom, hogy tudjak pihenni köztük, ha szükséges.

Susan Wendell azt tapasztalta, hogy „a saját testi és mentális korlátaikat konkrétan és élénken megélő emberek, vagy akik saját élettapasztalataik alapján megértik, hogy nem uralhatnak és nem irányíthatnak mindent, még a számukra legfontosabb dolgokat sem, azok sokkal nyitottabban közelednek fogyatékossággal élö társaikhoz, és kevésbé hajlamosak arra, hogy 'másoknak' tartsák őket” (Wendell, 2011: .61.) Számomra például magától értetődő volt, hogy segítő hivatást válasszak.

Susan Wendell (2011) szerint a fogyatékossággal élés tapasztalásait értéknek kellene tekinteni és be kellene építeni a kultúrába. Hiszem, hogy e saját testtel kapcsolatos tapasztalataink nélkül sem én, sem gyermekeim nem lennénk azok, akik vagyunk.

Susan Wendell Az elutasított test címü könyvének gondolatai különösen nagy hatással voltak rám. A szerzőnő fogyatékosságtörténetét olvasva nemcsak újraéltem saját betegségtörténetem, hanem segített átgondolni, újraértelmezni a 'mássághoz', a betegséghez, a fogyatékossághoz való viszonyomat is.

\section{Felhasznált irodalom}

Solomon, A. (2013). Szeress, bármi történjék. TED film. Retrieved from: https://www.ted.com/ talks/andrew_solomon_love_no_matter_what?language=hu\#t-144959

Wade, Cheryl Marie (2012). Tools for change. A változtatás eszközei. Film. Retrieved from: https:// www.youtube.com/watch?v=-zb4MOZZtzo

Wendell, Susan (2011). Az elutasitott test. Feminista filozófiai elmélkedés a fogyatékosságról. Fordította Vándor Judit. Budapest: ELTE BGGYK - ELTE Eötvös Kiadó. 